as excellent sources for different groups of readers: educators studying reference textbooks, researchers modeling reference transactions, and students with advanced knowledge in the development of expert systems in general and application of reference services in particular. Researchers and advanced students who study expert systems in other areas, such as cataloging and classification, will find individual chapters valuable for surveying the subject area. Readers will be delighted to find the extensive reference notes at the end of individual chapters and the bibliography at the end of the book.

Having said that, however, it is necessary to point out several of the book's weaknesses. Richardson's overall arrangement is problematic. The division of chapters into three headings (applications, problems, and progress) seems arbitrary, and the explanation of this tripartite structure in the preface (p. xii) is confused and unconvincing. Chapters 2 and 3 appear to be out of place in relationship to the book's other theoretical discussions on reference work. Richardson's own recommended teaching order (p. viii) is further evidence that the chapters are not arranged in logical order. The arrangement of chapters contributes to another problem in the book: the lack of a smooth transition between chapters. This problem might be due partially to the fact that some chapters were written as independent research papers, although Richardson could have solved it by giving users more help in his introduction. Finally, the historical research in this book, while contributing to the strength of chapters 1,4 , and 8 , also contributes to an imbalance in the depth of perspective on the subject areas treated. The comprehensive, well-documented historical reviews contrast sharply with the weaker generalizations and speculations on the future of expert systems. One wonders whether Richardson is as confident in, and positive about, the future of expert system research as he is about its history.

Research on expert systems enjoyed almost a decade of popularity among LIS researchers since its introduction to our field by Smith, who wrote her dissertation in 1979. Like much technology-related work, this research began with high hopes and enormous potential, and stimulated numerous experiments and prototypes. Researchers and advanced students spent countless hours reading textbooks on expert systems and learning about artificial intelligence programming languages. The common purpose among many designers of expert systems in LIS was, in most cases, to identify a very narrow domain of library operations and to codify what many saw as the simple rules and procedures of those operations into procedural knowledge of an expert system. But because the researchers studied narrow domain and simple routine library tasksand made no attempt to study the formidable issue of knowledge acquisition and representation-it proved impossible to transform their prototypes into successful operational systems. As the majority of projects faded or were forgotten near the end of $1980 \mathrm{~s}$, many researchers concluded that expert systems offered more limitations than possibilities and thus moved on to other topics. One of the few traces left from LIS expert system research is the keen awareness, among some researchers, of the need to study the conduct and learning process of LIS professional knowledge and skills. Richardson provides an important contribution to the area of LIS expert system research by analyzing reference teaching and reference transactions through historical studies and surveys.-Ling Hwey Jeng, School of Library and Information Science, University of Kentucky

\section{WORKS CrTED}

Alberico, Ralph and Mary Micco. 1990. Expert systems for reference and information retrieval. New York: Meckler.

Roysdon, Christine and Howard White. 1989. Expert systems in reference services. New York: Haworth.

Smith, Linda C. 1979. Selected artificial intelligence techniques in information retrieval systems research. Ph.D. diss., Syracuse University.

\section{The Closing of American Library} Schools: Problems and Opportunities. Larry J. Ostler, Therrin C. Dahlin, and J. D. Willardson. Contributions in Librarianship and Informa- 
tion Science, no. 85. Westport, Conn.: Greenwood, 1995. 176p. \$49.95 (ISBN 031328461X).

As library schools struggle to reinvent themselves for the Information Age, it is helpful to speculate as to why some of the most prestigious library schools in the country have closed in recent years. Library schools have been caught off guard in a suddenly hostile environment. However, this work does not go into the reasons why specific library schools closed. Instead, the authors present ideas for discussion.

This book begins with an examination of the history of library schools and higher education in the United States. The authors then go on to assess the present challenges that library schools face and possible strategies for overcoming these challenges. Finally, the authors present their own ideas for future library school programs and curricula. The lengthy section of appendixes (over half the book) provides examples of accreditation standards, mission statements, and library programs in use today.

Two chapters offer a historical perspective. The first outlines the evolution of higher education in the United States. Demographic, political, and economic factors all played a role in fashioning higher education into what it is today. Especially relevant is the section on professional education (p. 11), which was first elevated to higher education at Harvard around the turn of the century.

The next chapter provides a history of library education in America. It would have been interesting to learn more about how library schools became established in America but the authors present only a brief summary. The authors analyze Melvil Dewey's impact, claiming that Dewey "led the profession astray" (p. 23) by emphasizing practice over theory. The authors note the apparent lack of founding thinkers in library science, although they do mention a number of names, including Ralph Shaw and Jesse Shera. They return to this lack of a theoretical basis for library science in a later chapter.

In the next five chapters of the book, the authors discuss the present and future of library education in America. Chapter
4 discusses the "paradigm shift" that library schools have failed to notice. They cite Daniel Bell's argument that society is experiencing a shift "from an industrial to a postindustrial society where information has become a prime commodity" (p. 25). This shift began in the early 1960s. New trends in science and technology, such as computer networks, began to alter library work but library schools failed to notice these new trends. New organizational structures also emerged with new attitudes towards management, and library schools failed to recognize these new management styles as well.

Chapter 5 returns to the unanswered question that hangs over the faculty of every library school: is there a science to library science? If so, what is the body of scientific knowledge? If you ask one librarian, you get the answer that cataloging is the core of librarianship. If you ask another, you get the answer that helping the community is the core of librarianship. There is no agreement on a general body of knowledge. And the body of knowledge that does exist continues to fragment as schools devise new curricula.

In the next three chapters, the future of library education is considered. In Chapter 6, the authors present an argument for developing and implementing strategic plans in library schools because "the failure to plan effectively contributed to the decline and closing of some library schools" (p. 37). The authors give some examples of problems in planning and offer some solutions.

In Chapter 7, the processes of certification and accreditation are examined. The authors feel that more rigorous certification of professionals will strengthen the position of library schools. The authors believe that quantitative and qualitative standards should be established for librarians to receive certification, and for library programs to be accredited. The authors point to several other professions that have instituted basic standards. Accountants and teachers both have to meet professional standards in order to work in the profession or belong to professional organizations. Archivists have a certification process. The 
authors mention the American Library Association's standards for accreditation of library schools but they seem to feel that the ALA's standards do not meet the demands of the new marketplace that library schools face.

Chapter 8 presents the authors' ideas for redesigning library education, pointing to several areas in library education that need reform. The authors advocate strengthening the professional degrees by adding prerequisites for admission into a professional program, lengthening the degree program beyond a year, introducing areas of specialization into the curriculum, creating an undergraduate degree in information science, and abandoning accreditation for a free-market approach.

The authors present a new curriculum where undergraduate instruction would teach students basic library skills equivalent to paraprofessional skills in a library. The graduate programs would teach more theory, building on the basic skill set learned in undergraduate education. Doctoral study would involve further research and study of theory.

Although there is a rich academic history in the field of library and information science, it is doubtful that many students will want to study it for five or six years. Paraprofessional skills require mastering repetitive, mundane tasks such as filing or data processing. While these skills run a library, they are not worth studying at a university level, and do not form the basis of a liberal education-the foundation upon which many professions (including librarianship) is formed.

The authors also fail to take into account the low wages in the library field. What incentive is there to spend years in school preparing for a profession that pays below the average salary of other professions with comparable responsibilities? A professional school is only as good as the profession it serves. Among other reasons, students are willing to spend three years in law school because they know they can make a decent salary when they graduate. Library school graduates, on the other hand, are some of the lowest paid professionals in the country. Library schools cannot dictate the terms of the profession; they must instead respond to the needs of the profession.

When one examines the history of library education in America, one sees that library schools, as the authors point out, have always been pressured by external forces. Library schools emerged at the turn of the century as the number of libraries in America increased and demand for librarians grew. Andrew Carnegie and other captains of industry were willing to spend money to develop a network of libraries across the country. At the same time, professional schools began to affiliate with universities in an effort to improve quality. From the very beginning, library schools were tied to universitieswith Dewey opening the first library school at Columbia University in 1887.

After World War II, the United States government realized that scientific research and development was of critical importance to national security. Throughout the Cold War period, universities received massive research and development funding from the government. Library schools were affiliated with many of these universities. As the universities grew wealthy, the library schools shared the good fortune.

Since the Cold War ended, research and development have no longer been as great a national security issue. Government funding for research and development has dried up and universities that had grown fat from forty years of funding suddenly have had to become lean and mean. Library schools, never the glamorous centerpiece of any institution, have fallen victim to the budgetary ax as universities trimmed their costs in the new environment. Wedded to universities, library schools must share the fate of higher education.

There is a great need for information skills in the new postindustrial age described by the authors. The Internet presents a whole new chaotic world of information for catalogers to control and reference librarians to explore and explain. It is hoped that leaders of the library profession and of programs of library and information science will recognize this and maybe, one day, librarians will earn more Barrett Jones, RAND Corporation 